\title{
CONTENTS OF VOLUME 27
}

D. ACHARYA: See M. S. MISHRA

B. D. O. ANDERSON, W. A. COPPEL and D. J. CULLEN: Strong system equivalence (I)

A. P. BAKULEV, N. N. BOGOLUBOV (Jr.) and A. M. KURBATOV: The generalized Mayer theorem in the approximating Hamiltonian method

J. R. BLAKE: See G. R. FULFORD

N. N. BOGOLUBOV (Jr.): See A. P. BAKULEV

A. BROWN: A non-linear difference equation with two parameters. II

J. G. BURNELL, A. A. LACEY and G. C. WAKE: Steady states of the reactiondiffusion equations. Part III: Questions of multiplicity and uniqueness of solutions

A. L. CAREY and D. M. O'BRIEN: Existence and regularity results for Maxwell's equations in the quasi-static limit

D. J. CLARKE: See J. P. LOUIS

W. A. COPPEL: See B. D. O. ANDERSON

W. A. COPPEL and D. J. CULLEN: Strong system equivalence (II)

D. J. CULLEN: See B. D. O. ANDERSON

D. J. CULLEN: See W. A. COPPEL

B. DUSZCZYK, S. KOSINSKI and Z. WESOLOWSKI: Reflection of oblique shock waves in incompressible elastic solids

A. M. FINK: Optimal control in liver kinetics

G. R. FULFORD and J. R. BLAKE: Force distribution along a slender body straddling an interface

K. GOPALSAMY: Global asymptotic stability in a periodic Lotka-Volterra system

K. GOPALSAMY: Global asymptotic stability in an almost-periodic Lotka-Volterra system

I. F. GRANT and B. H. J. McKELLAR: Critical point behaviour of the diffusion length for radiative transfer

I. H. GRUNDY: Airfoils moving in air close to a dynamic water surface

JAMES M. HILL and BARRY D. HUGHES: On the general random walk formulation for diffusion in media with multiple diffusivities

BARRY D. HUGHES: See JAMES M. HILL

S. KOSINSKI: See B. DUSZCZYK

A. M. KURBATOV: See A. P. BAKULEV

A. A. LACEY: See J. G. BURNELL

G. LADAS and Y. G. SFICAS: Oscillations of higher-order neutral equations

JOHN LEKNER: Parseval's integral and the Jacobi expansions in series of Bessel functions

JOHN LOCKER and P. M. PRENTER: Splitting least squares and collocation procedures for two-point boundary value problems 
J. P. LOUIS and D. J. CLARKE: Exact edge wave solutions for some generalised exponential shelf topographies

M. A. D. MADURASINGHE and E. O. TUCK: Ship bows with continuous and splashless flow attachment

J. J. MAHONY and J. NORBURY: Asymptotic location of nodal lines using geodesic theory

B. H. J. McKELLAR: See I. F. GRANT

EVEN MEHLUM and JET WIMP: Spherical curves and quadratic relationships for special functions

JOHN BORIS MILLER: The foliage density equation revisited

M. S. MISHRA, S. NANDA and D. ACHARYA: Strong pseudo-convexity and symmetric duality in nonlinear programming

J. M. MURRAY: Simple nonlinear dual control problems

S. NANDA: See M. S. MISHRA

J. NORBURY: See J. J. MAHONY

D. M. O'BRIEN: See A. L. CAREY

D. M. O'BRIEN and R. S. SMITH: Transient electromagnetic response of a layered conducting medium at asymptotically late times

RENFREY B. POTTS: Ordinary and partial difference equations

P. M. PRENTER: See JOHN LOCKER

M. I. QURESHI: See CH. WALI MOHD

A. J. ROBERTS: Simple examples of the derivation of amplitude equations for systems of equations possessing bifurcations

Y. G. SFICAS: See G. LADAS

R. S. SMITH: See D. M. O'BRIEN

K. K. TAM: Criticality dependence on data and parameters for a problem in combustion theory

E. O. TUCK: See M. A. D. MADURASINGHE

G. C. WAKE: See J. G. BURNELL

CH. WALI MOHD and M. I. QURESHI: Expansion formulae for general triple hypergeometric series

G. J. WEIR: Surface mounted heat flux sensors

K.-D. WERNER: Boundary value control problems involving the Bessel differential operator

Z. WESOLOWSKI: See B. DUSZCZYK

JET WIMP: See EVEN MEHLUM

J. E. WOODS: On the dynamic analysis of a Leontief model with fixed capital 